\title{
Knowledge, attitude, practice, and predictors of female genital mutilation in Degadamot district, Amhara regional state, Northwest Ethiopia, 2018
}

\author{
Gedif Melese', Mulugeta Tesfa², Yewbmirt Sharew ${ }^{2}$ and Tsegaye Mehare ${ }^{3 *}$ (D)
}

\begin{abstract}
Background: Female genital mutilation is defined as all procedures that involve partial or total removal of external female genitalia, or other injuries to the female genital organs for cultural and religious purposes. In Ethiopia, the prevalence of female genital mutilation practice was $70.8 \%$ according to Ethiopian demographic and health survey 2016. This practice is against females' reproductive health rights with many serious consequences in physical, mental, social and psychological makeup. Therefore, this study aimed to assess knowledge, attitude, practice, and predictors of female genital mutilation in Degadamot district.
\end{abstract}

Methods: A community-based cross-sectional study design was conducted. Three hundred twenty-five mothers who had under 5 years old female children were selected using systematic random sampling from seven kebeles of Degadamot district. Data were collected using an adapted semi-structured face to face interview questionnaire. Data were entered into Epi-data version 3.1 and then exported to SPSS version 20 for analysis. Logistic regression analysis with 95\% confidence intervals was carried out to determine the associations between predictor variables and outcome variables.

Result: The finding of this study revealed that $56.6 \%$ of mothers had good knowledge about female genital mutilation and $54.2 \%$ of participants had a favorable attitude about female genital mutilation. $70.8 \%$ of under 5 years old female children's had female genital mutilation. Marital status $\mathrm{AOR}=7.19(95 \% \mathrm{Cl} 3.22-16.03)$, monthly income $\mathrm{AOR}=1.97(95 \% \mathrm{Cl} 0.26-3.81)$, custom $\mathrm{AOR}=2.13(95 \% \mathrm{Cl} 1.20-3.78)$, belief $\mathrm{AOR}=2.47(95 \% \mathrm{Cl} 1.39-4.39)$, value $A O R=0.37(95 \% \mathrm{Cl} 0.22-0.63)$, and attitude $A O R=24.4(95 \% \mathrm{Cl} 20.01-34.76)$ towards female genital mutilation had significant association with female genital mutilation practice.

Conclusion: Prevalence of FGM practices among female children of under 5 years of age was found to be high as compared to the national level (64\%). 56.6\% of mothers had good knowledge about FGM. The majority of the women had a favorable attitude to keep FGM practice among their under 5 years old daughters. Marital status, monthly income, custom, belief, value, and attitude had a significant association with FGM practice.

Keywords: Degadamot district, Female genital mutilation, Knowledge, Attitude, Practice

\footnotetext{
* Correspondence: tseyeshe96@gmail.com

${ }^{3}$ Department of Biomedical science, Collage of medicine and health science, Dilla University, Dilla, Ethiopia

Full list of author information is available at the end of the article
}

(c) The Author(s). 2020 Open Access This article is licensed under a Creative Commons Attribution 4.0 International License, which permits use, sharing, adaptation, distribution and reproduction in any medium or format, as long as you give appropriate credit to the original author(s) and the source, provide a link to the Creative Commons licence, and indicate if changes were made. The images or other third party material in this article are included in the article's Creative Commons. licence, unless indicated otherwise in a credit line to the material. If material is not included in the article's Creative Commons licence and your intended use is not permitted by statutory regulation or exceeds the permitted use, you will need to obtain permission directly from the copyright holder. To view a copy of this licence, visit http://creativecommons.org/licenses/by/4.0/ The Creative Commons Public Domain Dedication waiver (http://creativecommons.org/publicdomain/zero/1.0/) applies to the data made available in this article, unless otherwise stated in a credit line to the data. 


\section{Background}

Female Genital Mutilation (FGM) is all procedures that involve partial or total removal of the external female genitalia for non-medical reasons [1]. The practice of female genital mutilation/circumcision is dated back to ancient times [2]. Female circumcision has existed for over 4,000-5,000 years originating in a period predating God's covenant with Abraham to circumcise his people. Even if, there is no definitive evidence documenting when or why this ritual begun some theories suggest that FGM began in Egypt and was frequently performed by the ancient cultures of the Phoenicians, Hittites, and ancient Egyptians [3, 4]. Worldwide, in several countries FGM performed for different cultural reasons such as maintain the cleanliness of the vestibule by cutting secretory parts of the genitalia, discouraging promiscuity, aesthetic reasons, safeguarding and proof of virginity, and a prerequisite for honorable marriage $[5,6]$. In Ethiopia, girls who are not circumcised are considered as "promiscuity" as a result, have less chance of getting married [7]. The prevalence report estimated that more than 125 million girls and women have been subjected to FGM practice [8]. Two hundred million girls and women in the world are estimated to have undergone FGM, and another 15 million girls are at risk of experiencing it in the high prevalence countries [3, 9]. Despite a high level of knowledge regarding the complications of FGM and awareness of the global campaign against it, the prevalence of FGM in Africa countries such as Somali, Guinea, Mali, Djibouti, Sudan, and Egypt's is high $[10,11]$. In Ethiopia, the prevalence of FGM was $80 \%$ according to Ethiopia Demographic Health Survey (EDHS) 2000 [12], 75\% according to EDHS 2005 [13], and 70.8\% according to EDHS 2016 [14]. Concerning regional states in Ethiopia, the highest prevalence of FGM was found in Afar, Somali, Hadya, and Wolayta but less prevalent in Gambella and Tigray [13, 15]. According to EDHS 2005, the prevalence of FGM in the Amhara region was $74 \%$ [16] while the cross-sectional study in Lejet kebele, Dembecha woreda, Amhara region in 2014 report that $94 \%$ women and $34.2 \%$ of under five children were circumcised [17].

FGM practice is against females' reproductive health rights with many serious consequences in physical, mental, social and psychological makeup. Therefore, this study aimed to assess knowledge, attitude, practice, and predictors of female genital mutilation in Degadamot district.

\section{Methods}

\section{Study design and setting}

A community-based cross-sectional study design was conducted. The study was conducted in Degadamot district, Amhara regional state, Ethiopia. Degadamot is located on 409 Kilometer from Addis Ababa, capital city of Ethiopia. The total population of Degadamot district is 181,222 . Reproductive age woman constitutes of 42 , 732. The total area of Degadamot district is $833.23 \mathrm{~km}^{2}$, location $=11^{\circ} 4,60^{\prime \prime}$ North latitude and $37^{0} 24^{\prime}$ 59"East longitude $[18,19]$. This district has 33 rural Kebeles.

\section{Operational definition}

In this study, "knowledgeable" was defined as a score greater than or equal to a mean value of 5.8 from knowledge measuring ten questions of FGM. "Favorable attitude": mothers score greater than or equal to mean value of 29.25 from attitude measuring ten questions of FGM classified as favorable attitude. "Practice": respondents were classified as having FGM practice when there is at least one female daughter exposed to genital mutilation practice among under 5 years old female children in the family. "Belief": mental acceptance of acclaim as truth regardless of may or may not be supported by religion. "Custom": frequently repetition of the same standard, value and behavior in ordinary manner. "Value": accepting of rule, standard and behavior for a given community to have benefit.

\section{Sample size and sampling procedure}

The sample size was determined using single population proportion formula from Ethiopian demographic and health survey study, 2016(74\%) at 95\% confidence interval with a marginal error of 5 and $10 \%$ non-response rate, the total sample size was 325 mothers. The composition of the 33 kebeles in terms of ethnicity as well as religion is similar. From 33 Kebeles, seven kebeles (Debulocana, Shangi, Feresbet, Ziquala, Flatit, Michal and Gsagis) were selected randomly through the lottery method. In each of the selected kebeles, two points were identified to start selecting respondents by way of Households ( $\mathrm{HHs}$ ) and a house to house search for the eligible candidate until the required sample size achieved. In each household, the mother was selected as the study subject. Allocation of the desired number of households in each selected kebeles was done based on the number of households reported by respective kebeles (Fig. 1). The first household selected with lottery method, then, every 2nd household was included by a systematic random sampling method.

\section{Data collection}

A face to face-administered structured questionnaire was used to collect the data (Additional File 1). The questionnaire was prepared in English and then translated into Amharic, a local language. The questionnaire consisted of items assessing socio-demographic characteristics, knowledge, attitude, and practice of FGM. Seven experienced high school teachers for data 


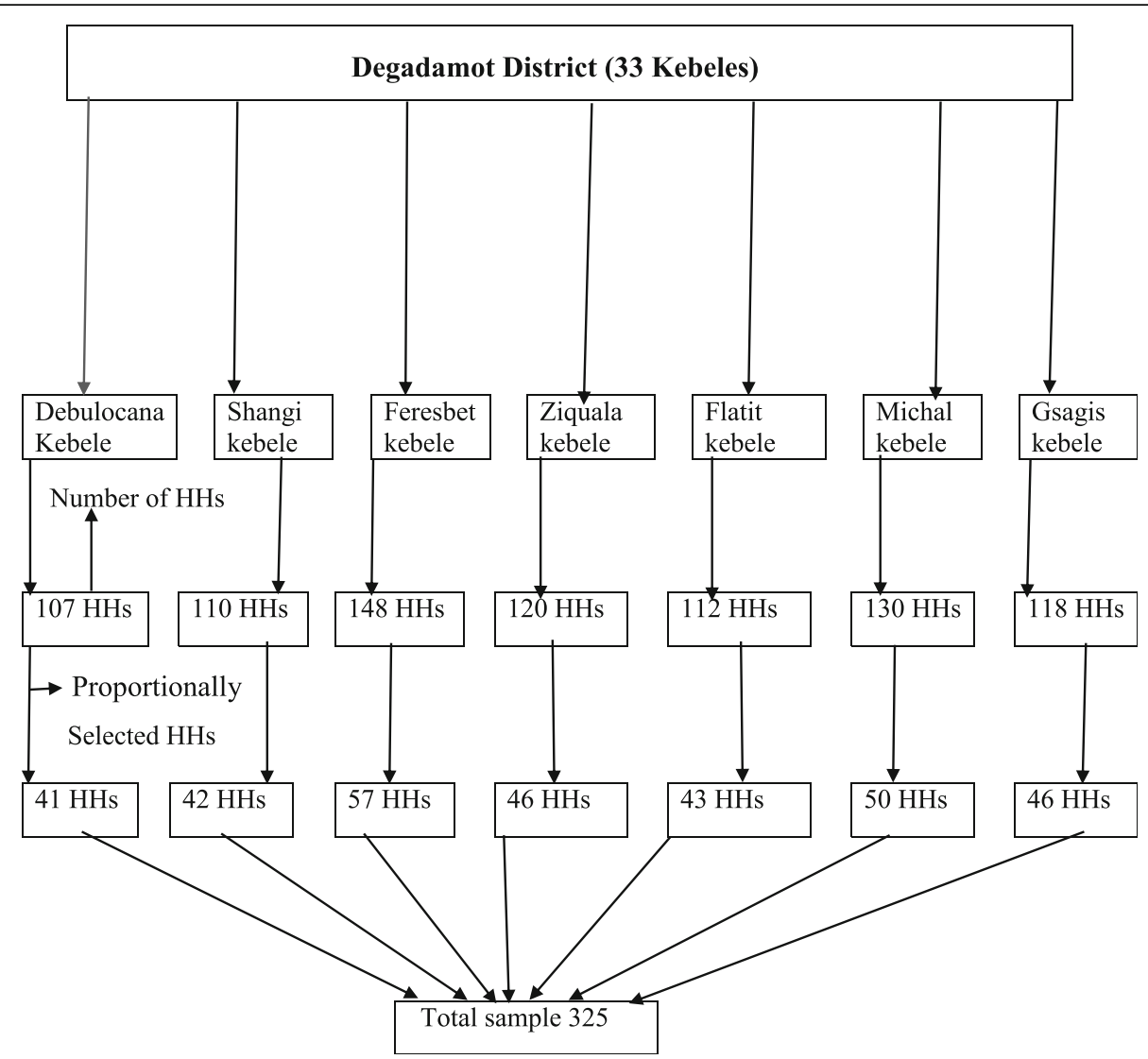

Fig. 1 Schematic presentation of the sampling procedure

collection and two experienced Master of Science (MSc) graduate health professionals for supervision were recruited. One day training was given for data collectors and a pre-test was done on 32 samples out of the main study area. During the pre-test, the questionnaire was assessed for its clarity, understandability, completeness, and time consumption. On each day until the end of the data collection period, trained data collectors were collected the data and submitted filled questionnaire to their respective supervisors daily. Subsequently, data were checked for completeness, accuracy, and consistency accordingly.

\section{Inclusion and exclusion criteria}

Inclusion criteria: All volunteer mothers who respond and had female children of under 5 years of age.

Exclusion criteria: Mothers who were seriously sick at the time of the interview.

\section{Data analysis}

After coding data entered and cleaned using EPI-DATA version 3.1 then exported to Statistical Package for Social Science (SPSS) version 20 for further analysis. Descriptive statistics were calculated for each variable. Bivariate logistic regression analysis was done to make a decision whether there is an association between dependent variable and independent variable and then, to select nominee variables for multivariate logistic regression. Variables with $p$-values of up to 0.05 in the bivariate logistic regression analysis were identified and fitted to the multiple logistic regression analysis to identify the independent effects of each variable to the outcome variable. The odds ratio with a 95\% confidence intervals (CI) was calculated to distinguish the occurrence and strength of associations, and statistical significance was affirmed if $p<0.05$.

\section{Results}

\section{General characteristics of study participants}

Hundred percent of the study participants were Orthodox Christians in religion and Amhara in ethnicity. Moreover, 245(75.4\%) study participants were married whereas in a profession almost all (98.5\%) of study participants were farmers. Regarding monthly income, slightly more than one-half (54.5\%) of study participants had less than 300 Ethiopia birrs. Almost two-thirds $(70.8 \%)$ of participants were unable to read and write (Table 1). 
Table 1 General characteristics of study participants in Degadamot district

\begin{tabular}{|c|c|c|}
\hline Variable & Frequency & Percentage (\%) \\
\hline \multicolumn{3}{|l|}{ Age in years } \\
\hline $15-24$ & 17 & 5.2 \\
\hline $25-34$ & 176 & 54.2 \\
\hline$\geq 35$ & 132 & 40.6 \\
\hline \multicolumn{3}{|l|}{ Marital status } \\
\hline Married & 245 & 75.4 \\
\hline Divorce & 43 & 13.2 \\
\hline Widowed & 37 & 11.4 \\
\hline \multicolumn{3}{|l|}{ Income level } \\
\hline$<300$ birr & 177 & 54.5 \\
\hline$\geq 300$ birr & 148 & 45.5 \\
\hline \multicolumn{3}{|l|}{ Educational status } \\
\hline Cannot read and write & 230 & 70.8 \\
\hline Can read and write (without formal education) & 60 & 18.5 \\
\hline Completed primarily education & 31 & 9.5 \\
\hline Completed from 9th ${ }_{-12}$ th & 4 & 1.2 \\
\hline \multicolumn{3}{|l|}{ Occupational status } \\
\hline Farmer & 320 & 98.5 \\
\hline Merchant & 5 & 1.5 \\
\hline \multicolumn{3}{|l|}{ Religion } \\
\hline Orthodox Christian & 325 & 100 \\
\hline \multicolumn{3}{|l|}{ Ethnicity } \\
\hline Amhara & 325 & 100 \\
\hline
\end{tabular}

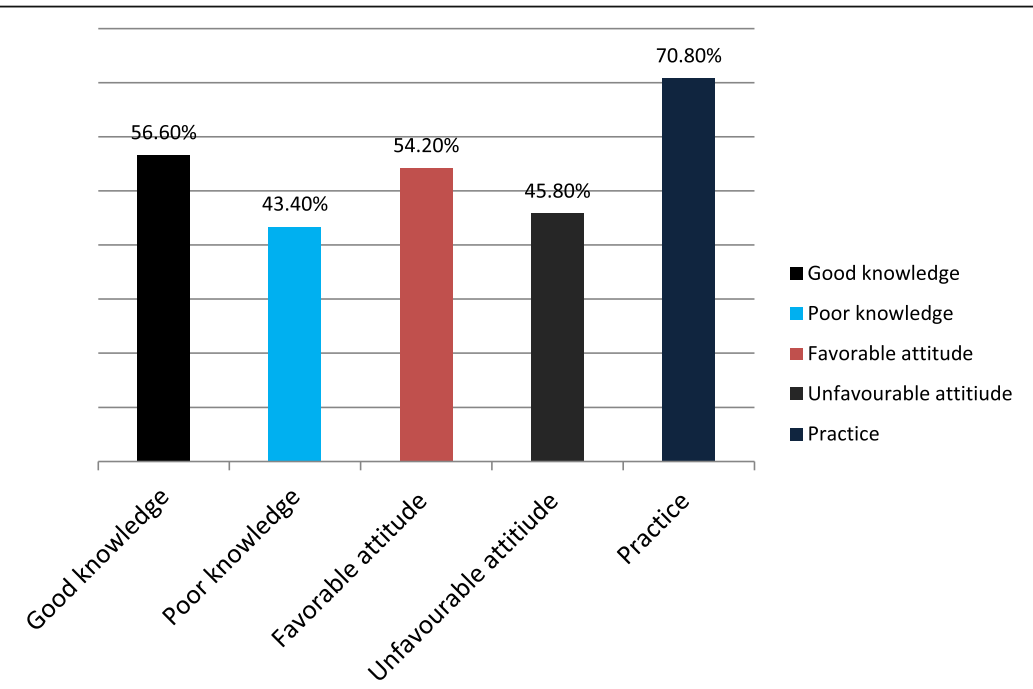

Fig. 2 Knowledge, attitude, and practice of the study participants for female genital mutilation in Degadamot District 
Table 2 Knowledge of study participants about genital mutilation in Degadamot district

\begin{tabular}{lll}
\hline knowledge question & Yes (percentage) & No (percentage) \\
\hline Do you know FGM has psychologically harmful? & $211(64.9 \%)$ & $114(35.1 \%)$ \\
Do you know FGM can decrease sexual pleasure? & $184(56.6 \%)$ & $141(43.4 \%)$ \\
Do you know FGM has a problem with health? & $183(56.3 \%)$ & $142(43.7 \%)$ \\
Do you know FGM has a contribution to HIV / AIDS transmission? & $184(56.6 \%)$ & $173(53.2 \%)$ \\
Do you know FGM brings complication during delivery? & $209(64.3 \%)$ & $141(43.4 \%)$ \\
Do you know FGM is harmful traditional practice? & $208(64 \%)$ & $152(46.8 \%)$ \\
Do you know the FGM has scar formation effect? & $168(51.7 \%)$ & $116(35.7 \%)$ \\
Do you know FGM has a negative side effect on health? & $188(57.8 \%)$ & $117(36 \%)$ \\
Do you know FGM is forbidden in the law? & $130(40 \%)$ & $157(48.3 \%)$ \\
Is there any other health problem concomitant with FGM? & $137(42.2 \%)$ & $195(60 \%)$ \\
\hline
\end{tabular}

\section{Knowledge of female genital mutilation}

One hundred eighty four (56.6\%) mothers had good knowledge of female genital mutilation. 184 (56.6\%) mothers knew FGM can increase transmission of HIV/ AIDS and decrease sexual pleasure 184 (56.6\%) (Fig. 2) and (Table 2).

\section{Attitude of female genital mutilation}

The attitude of mothers towards FGM practice was assessed nevertheless, more than half of the (54.2\%) participants had favorable attitudes and 149(45.8\%) participants had an unfavorable attitude (Fig. 2) and (Table 3).

\section{Female genital mutilation practice}

Among under 5 years old female children's in Degadamot districts, $230(70.8 \%$ ) had a practice of FGM. In this study circumcision was commonly practiced at 7 th day of postnatal age (11.5\%), 8th day of postnatal age (86.5\%), and 9th day of postnatal age (2\%) (Table 4) and (Fig. 2). Commonly Orthodox Christian religion follower's in Ethiopia baptized delivered mother with holy water around day 7th, 8th, 9th and FGM takes place accompanied with it.

\section{Predictors of knowledge of female genital mutilation} Income of respondents, marital status, belief, custom, and value had a significant association with knowledge and attitude about female genital mutilation. Married mothers were 5.64 times more likely to had good knowledge about female genital mutilation than widowed mothers $(\mathrm{AOR}=5.64 \mathrm{Cl}: 1.78,10.95)$. Those mothers who had a monthly income of $\geq 300$ birrs were 2.15 times more likely to had good knowledge than those mothers who had $<300$ birrs monthly income $(\mathrm{AOR}=$ 2.15Cl: $1.22,3.73)$. Belief and custom had association with knowledge about female genital mutilation $(\mathrm{AOR}=$ 2.74Cl: $1.71,4.27)$ and $(\mathrm{AOR}=3.14 \mathrm{Cl}: 1.82,5.43)$ respectively. Values had association with knowledge about female genital mutilation $(\mathrm{AOR}=2.89 \mathrm{Cl}: 1.68,4.98)$ (Table 5).

Table 3 Attitude of study participants about FGM practice in Degadamot districts

\begin{tabular}{|c|c|c|c|c|c|}
\hline Attitude question & Strongly agree & Agree & Neutral & Disagree & Strongly disagree \\
\hline Do you support FGM? & $35(10.8 \%)$ & $59(18.2 \%)$ & $24(7.4 \%)$ & $155(47.7 \%)$ & $51(15.7 \%)$ \\
\hline Does FGM can protect virginity of female? & $43(13.2 \%)$ & $97(29.8 \%)$ & $18(5.5 \%)$ & $142(43.7 \%)$ & $25(7.7 \%)$ \\
\hline Do you think uncircumcised females are not faithful & $49(15.1 \%)$ & $95(29.2 \%)$ & $21(6.5 \%)$ & $111(34.1 \%)$ & $49(15.7 \%)$ \\
\hline $\begin{array}{l}\text { Does uncircumcised female virginity can't easily rupture } \\
\text { during first time sex? }\end{array}$ & $11(3.4 \%)$ & $87(26.8 \%)$ & $13(4 \%)$ & $142(43.7 \%)$ & $25(7.7 \%)$ \\
\hline $\begin{array}{l}\text { Do you think uncircumcised females have decrease } \\
\text { sexual feeling? }\end{array}$ & $12(3.7 \%)$ & $95(29.2 \%)$ & $10(3.1 \%)$ & $47(14.5 \%)$ & $162(49.5 \%)$ \\
\hline Do you think FGM is good practice? & $22(6.8 \%)$ & $95(29.2 \%)$ & $14(4.3 \%)$ & $167(51.4 \%)$ & $27(8.3 \%)$ \\
\hline $\begin{array}{l}\text { Do you think uncircumcised female has problem } \\
\text { During child birth? }\end{array}$ & $58(17.8 \%)$ & $80(24.6 \%)$ & $11(3.4 \%)$ & $167(51.4 \%)$ & $27(8.3 \%)$ \\
\hline Will you voluntarily circumcise if you have daughter? & $28(8.6 \%)$ & $155(47.7 \%)$ & 19 (5.8\%) & $103(31.7 \%)$ & $20(6.2 \%)$ \\
\hline $\begin{array}{l}\text { Do you think uncircumcised female calls as a maid in } \\
\text { societies? }\end{array}$ & $23(7.1 \%)$ & !72 (52.9\%) & $5(1.5)$ & $90(27.7 \%)$ & $35(10.8 \%)$ \\
\hline Do you agree with FGM continuity for the future? & $22(6.8 \%)$ & $147(45.21)$ & $11(3.4 \%)$ & $136(41.8 \%)$ & $9(2.8 \%)$ \\
\hline
\end{tabular}


Table 4 Genital mutilation practice for under 5 years old daughters in Degadamot district

\begin{tabular}{llll}
\hline Practice based question & Yes (percentage) & No (percentage) \\
\hline Is FGM performed for your under 5 years old daughters & $230(70.8 \%)$ & $95(29.2 \%)$ & 9 th day \\
Practice based question & 7 th day & 8th day & 281 (86.5\%) \\
When circumcision takes place after birth? & $37(11.5 \%)$ & $7(2 \%)$ & \\
\hline
\end{tabular}

\section{Predictors of attitude of female genital mutilation}

Married mothers were 2.33 times more likely to had unfavorable attitude towards female genital mutilation than widowed $(\mathrm{AOR}=2.33 \mathrm{Cl}: 1.85,4.32)$. Those mothers whose monthly income $\geq 300$ birrs were 5.52 times more likely to had a unfavorable attitude than those mothers whose monthly income $<300$ birrs $(\mathrm{AOR}=5.25 \mathrm{Cl}: 3.18$, 9.65). The other significant associated factor with the attitude of mothers' is belief (AOR $=4.77 \mathrm{Cl}: 2.75,8.26)$. In this study custom and value also had significantly associated factors with attitude of mothers towards female genital mutilation $(\mathrm{AOR}=3.99 \mathrm{Cl}: 2.31,6.89)$ and $(\mathrm{AOR}=2.12 \mathrm{Cl}: 1.23,3.66)$ respectively (Table 5$)$.

\section{Predictors of female genital mutilation practice}

Marital status, monthly income, custom, belief, value, and attitude had a significant association with FGM practice. Married mothers were 7.19 time more likely to had practiced female genital mutilation for their under 5 years old female children's than widowed practiced of female genital mutilation for their under 5 years old female children's (AOR $=7.19 \mathrm{Cl}: 3.22,16.03)$. Those mothers whose monthly income of $\geq 300$ birrs were 1.97 times more likely to had practiced female genital mutilation than those who had $<300$ birrs monthly income $(\mathrm{AOR}=1.97 \mathrm{Cl}: 0.25,0.81)$. Custom and belief also significantly associated factors to the attitude of mothers towards $\mathrm{FGM}(\mathrm{AOR}=2.13 \mathrm{Cl}: 1.20,3.78)$ and $(\mathrm{AOR}=$ $1.47 \mathrm{Cl}: 1.39,4.39)$ respectively. This study also showed value had significant associated factors for FGM practice $(\mathrm{AOR}=0.37 \mathrm{Cl}: 0.22,0.63)$. Those mothers who had unfavorable attitudes toward FGM were 24.4 times more likely to had a practice of female genital mutilation for their under 5 years old female children than mothers with favorable attitude $(\mathrm{AOR}=24.4 \mathrm{Cl}: 20.01,347.59)$ (Table 6).

\section{Discussion}

Knowledge of female genital mutilation

$56.6 \%$ of study participants had knowledge about the harmful effect of FGM which is slightly good as compared to the studies conducted on mothers' knowledge about female genital mutilation in the Amhara region, Dembecha woreda and Oromia region [20,21]. The possible rationalization for this variation could be due to time interval and better health education provided by

Table 5 Bivariate and multivariate logistic regression analyses of factors associated with FGM knowledge and attitude in Degadamot district

\begin{tabular}{|c|c|c|c|c|c|c|c|c|}
\hline \multirow[t]{2}{*}{ Characteristic } & \multicolumn{2}{|c|}{ Knowledge } & \multirow[t]{2}{*}{ AOR (95\% Cl) } & \multirow[t]{2}{*}{$p$-value } & \multicolumn{2}{|l|}{ Attitude } & \multirow[t]{2}{*}{ AOR $(95 \% \mathrm{Cl})$} & \multirow[t]{2}{*}{$p$-value } \\
\hline & Good & Poor & & & favorable & Unfavorable & & \\
\hline \multicolumn{9}{|l|}{ Income } \\
\hline$\geq 300$ birr & 113 & 64 & $2.15(1.24,3.73)$ & 0.006 & 78 & 99 & $5.52(3.18,9.56)$ & 0.031 \\
\hline <300birr & 71 & 77 & 1 & & 83 & 65 & 1 & \\
\hline \multicolumn{9}{|l|}{ Marital status } \\
\hline Married & 161 & 84 & $5.64(1.78,10.94)$ & 0.001 & 102 & 143 & $2.33(1.85,4.32)$ & 0.002 \\
\hline Divorced & 14 & 29 & $1.42(0.52,3.87)$ & 0.49 & 29 & 14 & $0.45(0.17,1.36)$ & 0.692 \\
\hline Widowed & 9 & 28 & 1 & & 30 & 7 & 1 & \\
\hline \multicolumn{9}{|l|}{ Belief } \\
\hline No & 124 & 94 & $2.74(1.72,4.27)$ & $0.001^{*}$ & 115 & 49 & $4.77(2.75,8.26)$ & 0.001 \\
\hline yes & 60 & 47 & 1 & & 105 & 56 & 1 & \\
\hline \multicolumn{9}{|l|}{ Custom } \\
\hline No & 123 & 55 & $3.14(1.82,5.43)$ & $0.001^{*}$ & 63 & 115 & $3.99(2.31,6.89)$ & 0.001 \\
\hline yes & 61 & 86 & 1 & & 98 & 49 & 1 & \\
\hline \multicolumn{9}{|l|}{ Value } \\
\hline No & 130 & 54 & $0.28(0.16,0.49)$ & $0.001^{*}$ & 64 & 123 & $2.12(1.22,3.66)$ & 0.007 \\
\hline yes & 54 & 87 & 1 & & 97 & 41 & 1 & \\
\hline
\end{tabular}


Table 6 Bivariate and multivariate logistic regression analyses of factors associated with FGM practice in Degadamot district

\begin{tabular}{|c|c|c|c|c|c|}
\hline \multirow[t]{2}{*}{ Characteristics } & \multicolumn{2}{|l|}{ FGM } & \multirow[t]{2}{*}{ COR $(95 \% \mathrm{Cl})$} & \multirow[t]{2}{*}{ AOR $(95 \% \mathrm{Cl})$} & \multirow[t]{2}{*}{$p$-value } \\
\hline & Yes & $\mathrm{No}$ & & & \\
\hline \multicolumn{6}{|l|}{ Marital status } \\
\hline married & 200 & 45 & 8.205 (3.882-17.343) & 7.19 (3.223-16.03) & $0.001^{*}$ \\
\hline divorced & 17 & 26 & $1.207(0.486,3.001)$ & $0.483(0.171,1.369)$ & 0.171 \\
\hline widowed & 13 & 24 & 1 & 1 & \\
\hline \multicolumn{6}{|l|}{ Believe } \\
\hline no & 139 & 32 & $3.007(1.822,4.962)$ & $2.472(1.391,4.394)$ & 0.003 \\
\hline yes & 91 & 63 & 1 & 1 & \\
\hline \multicolumn{6}{|l|}{ Income } \\
\hline > 300birr & 92 & 56 & $2.154(1.324,3.504)$ & $1.97(0.258,3.810)$ & 0.027 \\
\hline$<300$ birr & 138 & 39 & 1 & 1 & \\
\hline \multicolumn{6}{|l|}{ Value } \\
\hline no & 150 & 37 & $2.939(1.794,4.815)$ & $0.374(0.222,0.632)$ & $0.01^{*}$ \\
\hline yes & 80 & 58 & 1 & 1 & \\
\hline \multicolumn{6}{|l|}{ Custom } \\
\hline no & 141 & 37 & $2.483(1.521,4.055)$ & $2.133(1.203,3.7830)$ & $0.001^{*}$ \\
\hline yes & 89 & 58 & 1 & 1 & \\
\hline \multicolumn{6}{|l|}{ Knowledge } \\
\hline good & 92 & 138 & $1.38(0.832,2.27)$ & $1.21(0.134,2.212)$ & 0.140 \\
\hline poor & 31 & 64 & & & \\
\hline \multicolumn{6}{|l|}{ Attitude } \\
\hline unfavorable & 93 & 148 & $25.5(20.155,349.47)$ & $24.4(20.008,347.59)$ & $0.001^{*}$ \\
\hline favorable & 2 & 82 & 1 & 1 & \\
\hline
\end{tabular}

health extension workers to the study participants in the current study area. The other justification for differences might be due to differences in place of the studies that might be explained by different strategies in promoting and creating awareness about the terrible health consequences of FGM and cultural differences in study participants especially in Oromia region where most of the people are Muslims. However, the study done in Jijiga showed that mother's knowledge about the terrible effect of FGM was higher. This might be due to the fact that massive governmental and nongovernmental intervention in Somalia region to create awareness and stop the practice [22]. Hence, the mother's knowledge on the terrible effect of FGM is very poor in this study area that needs intervention from health professionals, government and other concerned bodies.

\section{Attitude of female genital mutilation}

$54.2 \%$ of study participants had a favorable attitude against female genital mutilation. It was inconsistent with the study done in Amhara region, Oromia region, and Gambia [20,21, 23]. The possible explanation for this difference might be due to the time gap and socio- demographic background different particularly with Gambia. Another possible rationalization for this difference might be religious by which all of the study participants in the current study were orthodox Christians.

\section{Predictors of knowledge and attitude for female genital mutilation}

Income of respondents, marital status, belief, custom, and value had a significant association with knowledge and attitude of mothers about the terrible effect of female genital mutilation. Those mothers who were married had good knowledge and unfavorable attitude about the terrible effect of female genital mutilation than widowed. The possible justification for this association was those mothers who were married had experience terrible effects especially, during sexual practice how it is painful and lengthen labor with its horrible consequences, even if, no other study which supports it.

Mothers whose monthly income $\geq 300$ Ethiopian birrs were more likely to had good knowledge and unfavorable attitude towards the effect of FGM than whose monthly income $<300$ Ethiopian birrs. This finding is consistent with studies conducted in Jimma zone, 
Southwest Ethiopia [24], Maryland USA [25], WHO [26]. This might be due to the fact that economically well-off families were more likely to expose to digital and non-digital educational programs and acquired knowledge to develop unfavorable attitude FGM. However, this observation was contrary to most studies' findings which showed that the knowledge, attitude, and practice of FGM is independent of economic status. Moreover, the knowledge and attitude of mothers about FGM was significantly predicted by belief, custom, and value. Comparable results were seen by a study in Sudan [3, 27]. The possible justification for this might be an individual's belief, custom and values are preloaded social and cultural identities as well as important factors for having a negative attitude towards FGM and acquire knowledge.

\section{Predictors of female genital mutilation practice}

$70.8 \%$ of female children age fewer than 5 years old had genital mutilation in Degadamot woreda which was lower than the study conducted in Eastern Sudan [28] and Kenya [26]. The possible explanation for this difference could be due to the difference in study participants sample size and socio-demographic difference. Another possible rationalization for this difference might be the difference in culture and religion because in this study all the study participants were orthodox Christians as compared to Sudanese who were mostly Muslims. However, this study finding was lower than the study conducted in Dembecha woreda, Amhara region [21]. The possible reason for this difference could be the time gap otherwise socio-cultural and religious aspects were almost similar.

Marital status, monthly income, custom, belief, value, and attitude had a significant association with female genital mutilation practice. Those married women were more likely to had practiced female genital mutilation for their under 5 years old female children's than widowed women practiced female genital mutilation for their under 5 years old female children's. However, married women had experienced pain particularly during sexual practice and prolong labor with its horrible consequences, their daughters might be circumcised to avoid promiscuity and be a candidate for honorable marriage. Those women who had a monthly income of $\geq 300$ birrs were more likely to had practiced female genital mutilation than those who had less than 300 birrs monthly income. This finding was contrary to the studies conducted in Maryland USA [25], WHO [26]. This difference might be due to study sitting and culture. However, most studies' findings showed that the knowledge, attitude, and practice of FGM are independent of economic status.

Custom, belief, and value of women also other important significant factors associated with female genital mutilation practices. It was in line with a study done in Jimma zone [24] and Eastern Ethiopia [29]. FGM is performed in line with tradition and social norms and to uphold their status and honor of the entire family. Belief, custom, and values are environmentally acquired indigenous identities that regulate individual's perception towards terrible effect FGM practices [29, 30]. Attitude was also another significantly associated factor with FGM practice. Women who had unfavorable attitude against FGM were more likely to practice FGM on their daughters than women who had a favorable attitude against FGM. It was consistent with study done on Somali region, particularly female participants [29]. The possible justification for this might be the practice of FGM is the result of poor knowledge and unfavorable attitude against the harmful effects of FGM. Women with good knowledge of the harmful effects of FGM more likely not to support the practice and in turn not engage the practice. This means educate women about the harmful effects of FGM will aid them to build up constructive attitude to impede the practice.

\section{Conclusion}

The prevalence of FGM practices among female children of under 5 years of age was found to be high as compared to the national level (64\%). Most women had good knowledge about FGM but majority of them had a favorable attitude to keep FGM among their daughters. Marital status, monthly income, custom, belief, value, and attitude had a significant association with FGM practice.

\section{Recommendations}

Government has to take a strong legal measurement of female genital mutilation. Regional Health Bureau and Zonal Health Offices must plan health education program about the ill health effects of FGM and provide community education program. Health profession has to give attention during antenatal care, postnatal care, and other maternal health services in creating awareness about ill health effects of FGM. Lastly, further qualitative research is recommended.

\section{Abbreviations \\ AOR: Adjust odds ratio; COR: Crude odds ratio; EDHS: Ethiopia Demographic Health Survey; FGM: Female genital mutilation; KAP: Knowledge attitude and practice; HHs: House holds; SPSS: Statistical package for social science}

\section{Acknowledgments}

We would like to acknowledge Degadamot district health office coordinator for his kind help in the collection of data for this study.

\section{Authors' contributions}

GM: designed the study, developed the questionnaire, train data collectors, supervises data collection process, performed data clerk and data analysis and interpreted the result. MT: contributed to the development of the overall study concept, design of the study, drafted and reviewed the paper YS: contributed to the development of the overall study concept, design of the study, drafted and reviewed the paper as well contribute as a drafter 
and writer of the manuscript.TM: Contribute to the analysis of the result plus the main man of manuscript writing. Then, all authors read and approved the final manuscript

\section{Funding}

Not applicable.

\section{Availability of data and materials}

The datasets generated and/or analyzed during the current study are available from the corresponding author on reasonable request.

\section{Ethics approval and consent to participate}

Ethical clearance and approval to conduct this research were obtained from Debre Markos University College of Health Sciences Institutional Research Ethics Review Committee (IRERC). Besides permission warranted from the Degadamot district health bureau and again permission warranted from each respected kebeles. Since the data collected in this study was a part of medical centers registration and the mode of data collection was noninvasive verbal informed consent was obtained from each study participant before data collection. This procedure for obtaining verbal consent to participate was approved by the Institutional Research Ethics Review Committee. Confidentiality of the data was maintained by excluding their identifiers. All participants were involved in this study only with their willingness.

\section{Consent for publication}

Not applicable.

\section{Competing interests}

The author declares that they have no competing interests.

\section{Author details}

${ }^{1}$ Department of public health, College of Health Sciences, Debre Markos University, Debre Markos, Ethiopia. ${ }^{2}$ Departments of Midwifery, College of Health Sciences, Debre Markos University, Debre Markos, Ethiopia.

${ }^{3}$ Department of Biomedical science, Collage of medicine and health science, Dilla University, Dilla, Ethiopia.

Received: 31 July 2019 Accepted: 30 July 2020

Published online: 14 August 2020

\section{References}

1. EN: Female genital mutilation. Report of a research methodological workshop on estimating the prevalence of FGM in England and Wales. London. 2012

2. Teixeira ALLM. Estimating the prevalence of female genital mutilation in Portugal. Public Health. 2016;139:53-60.

3. Werunga DS. Transformation of female circumcision among the Kipsigis of Bomet County: Kenya; 1945-2014; 2017.

4. Van Baelen L, Ortensi L, Leye E. Estimates of first-generation women and girls with female genital mutilation in the European Union, Norway and Switzerland. The European Journal of Contraception \& Reproductive Health Care. 2016;21(6):474-82

5. Gale T: Encyclopedia of bioethics; , volume 1. In. Edited by Stephen G. Post eic, vol. volume 1, 3rd ed edn.

6. Saleem RA, Othman N, Fattah FH, Hazim L, Adnan B. Female genital mutilation in Iraqi Kurdistan: description and associated factors. Women Health. 2013;53(6):537-51.

7. SA: Activity Report of Ethiopian Women Layers association. In., vol. 10; 2000: 21

8. Leye E, Powell RA, Nienhuis G, Claeys P, Temmerman M. Health care in Europe for women with genital mutilation. Health Care Women Int. 2006; 27(4):362-78.

9. Abdulcadir J, Margairaz C, Boulvain M, Irion O: Care of women with female genital mutilation/cutting. Swiss Med Wkly 2011, 141(1-2)

10. Khosla R, Banerjee J, Chou D, Say L, Fried ST. Gender equality and human rights approaches to female genital mutilation: a review of international human rights norms and standards. Reprod Health. 2017;14(1):59.

11. Waigwa S, Doos L, Bradbury-Jones C, Taylor J. Effectiveness of health education as an intervention designed to prevent female genital mutilation/ cutting (FGM/C): a systematic review. Reprod Health. 2018;15(1):62.

12. Ethiopian Demographic and Health Survey. In.; 2000
13. Assefa R: Factors affecting the practice of female genital mutilation of Ethiopian women. Addis Abeba university; 2011

14. Mehari LE. The Association of Female Genital Mutilation in sexual behaviors and marriageability, Ethiopia DHS 2016; 2018.

15. Gebremichael T. Female genital mutilation and birth complications, Jijiga town. Eastern Ethiopia: Addis Ababa University; 2002.

16. Central statistical authority (CSA) and Ethiopian demographic and health survey study. In.; 2005

17. Moges NA, Mullu G, Gedfew M, Redi M, Molla M, Ayenew S, Fentahun S, Adisie S, Dagnew Z. Knowledge, attitude and practice of women towards female genital mutilation in Lejet Kebele, Dembecha Woreda, Amhara regional state, northwest, Ethiopia, 2014. J Gynecol Obstetr. 2015;3(2):21-5.

18. Fikre AA, Demissie M. Prevalence of institutional delivery and associated factors in Dodota Woreda (district), Oromia regional state, Ethiopia. Reprod Health. 2012:9(1):33.

19. Wako WG, Kassa DH. Institutional delivery service utilization and associated factors among women of reproductive age in the mobile pastoral community of the Liban District in Guji zone, Oromia, southern Ethiopia: a cross sectional study. BMC Pregnancy Childbirth. 2017:17(1):144.

20. Belda S, Tololu A. Knowledge, attitude and practice of mothers towards female genital mutilation in south west Shoa zone, Oromia region, Ethiopia. MOJ Public Health. 2017:6(2):279-86.

21. Moges NA, Mullu G, Gedfew M. Attitude and practice of women towards female genital mutilation in Lejet Kebele, Dembecha Woreda, Amhara regional state, northwest, Ethiopia, 2014. J Gynecol Obstet. 2015;3:21-5.

22. Hussein MA, Abdi AA, Mohammed M. Knowledge, attitude and practice of female genital mutilation among women in Jigjiga town, Eastern Ethiopia. Gaziantep Med J. 2013;19(3):164-8.

23. Kaplan A, Hechavarría S, Martín M, Bonhoure I. Health consequences of female genital mutilation/cutting in the Gambia, evidence into action. Reprod Health. 2011:8(1):26.

24. Argaw A, Fisseha N: Prevalence of female genital mutilation and attitude of mothers towards it in serbo town. Ethiop J Health Sci 2002, 12(2): 69-68,

25. Carr D. Female genital cutting. Findings from the Demographic and Health Surveys program; 1997.

26. Organization WH. A systematic review of the health complications of female genital mutilation including sequelae in childbirth. Geneva: World Health Organization; 2000.

27. Islam MM, Uddin MM. Female circumcision in Sudan: future prospects and strategies for eradication. Int Fam Plan Perspect. 2001;27:71-6.

28. El Dareer A. Complications of female circumcision in the Sudan. Trop Dr. 1983;13(3):131-3.

29. Abathun AD, Sundby J, Gele AA. Attitude toward female genital mutilation among Somali and Harari people, Eastern Ethiopia. Int J Women's Health. 2016;8:557.

30. Fund UNCs, Gupta GR. Female genital mutilation/cutting: a statistical overview and exploration of the dynamics of change. Reprod Health Matters. 2013:21:184-90.

\section{Publisher's Note}

Springer Nature remains neutral with regard to jurisdictional claims in published maps and institutional affiliations.

Ready to submit your research? Choose BMC and benefit from:

- fast, convenient online submission

- thorough peer review by experienced researchers in your field

- rapid publication on acceptance

- support for research data, including large and complex data types

- gold Open Access which fosters wider collaboration and increased citations

- maximum visibility for your research: over $100 \mathrm{M}$ website views per year

At BMC, research is always in progress.

Learn more biomedcentral.com/submissions 